\title{
SIMULTANEOUS QUANTITATION OF SERUM HBV DNA AND HBeAg CAN DISTINGUISH BETWEEN SLOW AND FAST VIRAL RESPONSES TO ANTIVIRAL THERAPY IN PATIENTS WITH CHRONIC HEPATITIS B
}

Luiz Caetano DA SILVA, Maria Luiza da NOVA, Suzane Kioko ONO-NITA, João Renato Rebello PINHO, Roberta SITNIK, Vera Aparecida dos SANTOS \& Flair José CARRILHO

\begin{abstract}
SUMMARY
Background: The quantitation of serum HBeAg is not commonly used to monitor viral response to therapy in chronic hepatitis B. Methods: In this study, 21 patients receiving varying therapies were followed and their viral response monitored by concomitant viral load and $\mathrm{HBeAg}$ quantitation in order to study the meaning and the kinetics of both parameters. Results: It was possible to distinguish between three different patterns of viral response. The first was characterized by a simultaneous decrease in serum HBV DNA and HBeAg. The second pattern was characterized by a decrease in serum HBeAg but persistent detection of HBV DNA. The third pattern was characterized by undetectable HBV DNA with persistent HBeAg positivity, which points to a non-response (Pattern III-B) except when HBeAg levels showed a slow but steady drop, characterizing a "slow responder" patient (Pattern III-A). Conclusions: The first pattern is compatible with a viral response. A long-term HBeAg seropositivity with a slow and persistent decrease (Pattern III-A) is also compatible with a viral response and calls for a prolongation of anti-viral treatment.
\end{abstract}

KEYWORDS: Hepatitis B; Serological markers; Treatment response; Treatment follow-up.

\section{INTRODUCTION}

The management of chronic hepatitis B has been the subject of many reviews over the last few years ${ }^{4,11,19,23,24}$. Updates to the recommendations for monitoring patients infected with hepatitis B virus (HBV) were recently published ${ }^{20,25}$, and in them, as well as recent publications on this subject, serum Hepatitis e antigen ( $\mathrm{HBeAg}$ ) is considered only qualitatively with no evaluation of its expression (quantitation) as a tool for monitoring patients undergoing treatment ${ }^{20,25}$.

According to KEEFE et ll. $^{20}$, the quantitation of HBeAg has not been widely used, is expensive, and available data about the predictive value of HBeAg serostatus remains limited. The same authors mention that approximately one third of patients with serum HBV DNA levels lower than $10^{4}$ copies will seroconvert, suggesting a close relationship between HBV DNA suppression and the likelihood of seroconversion. $\mathrm{HBe} \mathrm{Ag}$-positive chronic hepatitis $\mathrm{B}$, considered as the classical form, is characterized by a stable high level viremia $\left(10^{7}-10^{10} \mathrm{HBV}\right.$ copies $\left./ \mathrm{mL}\right)$, whereas $\mathrm{HBeAg}$-negative hepatitis B is characterized by a less stable and severe viremia, or less than $10^{6}$ copies $/ \mathrm{mL}^{30}$.

Several different types of quantitative assays based on signal or target amplification are available for viral DNA, including high sensitivity polymerase chain reaction (PCR)-based methods that measure serum HBV DNA levels with a wide dynamic range ${ }^{1,25}$. Nowadays, real-time PCR assays are preferably used ${ }^{25}$.

The maximum HBV DNA viral load detected in patients with chronic $\mathrm{HBV}$ is not well established and may depend on the quantitative technique used to measure it. Thus, CORDEN et al. ${ }^{5}$ measured HBV DNA with the Chiron Amplicor HBV DNA Monitor Assay and found that the viral load was between $4 \mathrm{X} 10^{2}$ and $1.2 \times 10^{9}$ copies $/ \mathrm{mL}$. In HBeAg-positive patients, they found HBV DNA levels of up to $10^{9.5} \mathrm{copies} / \mathrm{mL}$. By using in-house end-point dilution PCR based on Kaneko's method ${ }^{17,18}$, our group found levels of up to $3 \mathrm{X} 10^{12}$ copies $/ \mathrm{mL}^{6,8}$. Also, using real-time PCR, HO et al. ${ }^{14}$ found median levels of $1.5 \times 10^{7}$ copies $/ \mathrm{mL}$, and JARDI et al. ${ }^{16}$ found median a serum HBV DNA viral load of 9.2X10 copies/ $\mathrm{mL}$ (range $2.9 \times 10^{5}-4.8 \times 10^{11}$ ).

For $\mathrm{HBeAg}$-positive chronic hepatitis B patients, the main goals for treatment are $\mathrm{HBeAg}$ loss, seroconversion to anti-HBe, normalized alanine aminotransferase (ALT) levels, and the suppression of viremia to undetectable levels ${ }^{25}$. However, it has been consistently observed that lamivudine (LAM) or adefovir dipivoxil (ADV) produces a rapid and dramatic decrease in viremia, but a lower proportion of patients exhibit serum HBeAg $\operatorname{loss}^{30}$. This important aspect was also emphasized by

University of São Paulo School of Medicine, Department of Gastroenterology, Hepatology Branch.

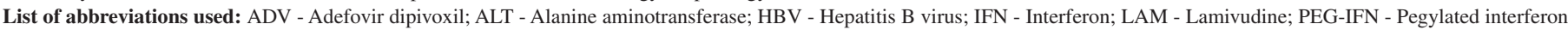

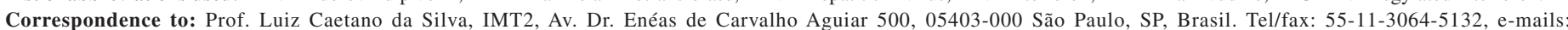

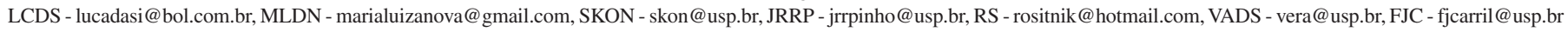


DA SILVA, L.C.; NOVA, M.L.; ONO-NITA, S.K.; PINHO, J.R.R.; SITNIK, R.; SANTOS, V.A. \& CARRILHO, F.J. - Simultaneous quantitation of serum HBV DNA and HBeAg can distinguish between slow and fast viral responses to antiviral therapy in patients with chronic hepatitis B. Rev. Inst. Med. trop. S. Paulo, 51(5): 261-268, 2009.

NEUMANN ${ }^{26}$. It is worth mentioning that the production of $\mathrm{HBeAg}$ is not dependent on the formation of HBV DNA, but it reflects the level of HBV core/precore gene expression in the liver ${ }^{34}$.

The role of HBeAg quantitation has already been addressed by some authors ${ }^{13,28}$. PERILLO et al. $^{28}$ found that the baseline HBeAg concentration is the best independent predictor of a patient's response to interferon-alpha (IFN- $\alpha$ ) when compared to baseline HBV DNA levels. Furthermore, it was observed, in this study and another ${ }^{12,13}$, that a steep decline in the $\mathrm{HBeAg}$ concentration during the first weeks of therapy was predictive of an antiviral response. A long-term study on the serial quantitation of $\mathrm{HBeAg}$ demonstrated that a high serum level (> $100 \mathrm{IU} /$ $\mathrm{mL}$ ) at week 24 of therapy with peginterferon alpha-2a (Peg-IFN- $\alpha 2 \mathbf{a})$ had an excellent negative predictive value; less than $5 \%$ of patients achieved $\mathrm{HBeAg}$ seroconversion at week $72^{10}$.

During LAM therapy, different types of changing patterns have been observed in relation to levels of $\mathrm{HBeAg}$ pretreatment, and they have been categorized into three groups: "decrescendo" ("falling"), "decrescendo-crescendo" ("falling-rising"), and "no changing" or "fluctuating" 27,31 . These patterns determined by serial monitoring during LAM therapy allowed the prediction of the treatment response as well as early recognition of a viral breakthrough. However, a simultaneous determination of HBV DNA was not performed.

It is worth mentioning that, in $\mathrm{HBeAg}$-positive patients, entecavir was found to be more potent than LAM and resulted in undetectable HBV DNA by PCR in $67 \%$ of patients at week 48, compared to $36 \%$ of patients treated with $\mathrm{LAM}^{3}$. However, the $\mathrm{HBeAg}$ seroconversion rate was similar in the two groups, $21 \%$ and $18 \%$. Despite these interesting and valuable observations, serial quantitative determinations of serum $\mathrm{HBeAg}$ have not been routinely carried out during the last few years and have not been mentioned in some recent recommendations ${ }^{20,25}$.

Using serial quantitative PCR for HBV DNA and a simultaneous quantitative $\mathrm{HBeAg}$ assay, we previously observed an interesting dissociation between HBV DNA and HBeAg in some patients. Our aim is to show that a simultaneous decrease in HBV DNA and HBeAg levels, in addition to a slow but stepwise decreasing pattern of $\mathrm{HBeAg}$ levels in some patients, may predict the negative $\mathrm{HBeAg}$ response despite a very prolonged positive response during antiviral therapy. This is particularly important because serum HBV DNA levels may decrease to undetectable levels soon after initiating therapy with LAM or other drugs $\mathrm{s}^{8,26,30,34}$ and can not be used further for monitoring the treatment response.

\section{PATIENTS AND METHODS}

Patients: Twenty-one HBeAg-positive patients with chronic hepatitis B were enrolled in the study (Table 1). Sixteen patients received LAM and five patients received IFN- $\alpha$ plus LAM (Table 2).

In this phase of the study, we detected some patterns of the viral response (described below) in 11 of the 16 patients given LAM and in four of the five patients given IFN- $\alpha$ plus LAM.

Nine patients who did not respond to antiviral therapy, and one who presented with a relapse after LAM withdrawal, were retreated as shown
Table 1

Demographic and baseline data for naïve patients (first phase)

\begin{tabular}{ll}
\hline Sex $(\mathrm{M} / \mathrm{F})$ & $16 / 5$ \\
Age (years) & $9-65( \pm 38)$ \\
Caucasians/Asians & $14 / 7$ \\
HBV DNA (log) & $5.41-12.48( \pm 9.26)$ \\
ALT (xUNL) & $0.7-8.8( \pm 3.24)$ \\
Chronic hepatitis/Liver cirrhosis & $16 / 5$ \\
First therapy & No. of patients \\
$\quad$ Lamivudine (LAM) & 16 \\
$\quad$ IFN + LAM & 5 \\
Follow-up (months) & $34-133( \pm 91)$ \\
\hline
\end{tabular}

in Table 3. Three patients (5, 6, and 13) had to receive another series of therapy after the second trial.

Patient ages varied from nine to 65 years (mean $38 \mathrm{yr}$ ) and they were studied during a period of 34 to 133 months (Table 1). All patients had Hepatitis B surface antigen (HBsAg) in their serum for at least six months and detectable HBV DNA. Patients were excluded if they were also infected with hepatitis $\mathrm{C}$ virus, hepatitis D virus, or human immunodeficiency virus (HIV). Patients who withdrew prematurely from the study or had only minimal lesions (inactive HBsAg carrier state) were also excluded. All patients gave informed consent for the study, which was approved by the Institutional Review Board (Hospital das Clínicas - University of São Paulo School of Medicine).

Treatment schedules and primary endpoints: Sixteen patients received monotherapy with oral LAM at a dose varying from $150 \mathrm{mg}$ to $300 \mathrm{mg}$ per day for $12 \mathrm{months}$ and $150 \mathrm{mg}$ /day thereafter as previously described $^{8}$. Three out of four patients with liver cirrhosis received 150 $\mathrm{mg}$ /day from the beginning (Table 2). Therapy with IFN- $\alpha$ (3 to $5 \mathrm{MU}$ three times a week) plus LAM (150 mg/day) was initially given to four patients (Table 2). Another patient was submitted to combined therapy with Peg-IFN- $\alpha 2 b$ and LAM because of high serum levels of HBV DNA and $\mathrm{HBeAg}$ and a slight increase in ALT. In our experience, patients with such baseline values are prone to develop resistance to monotherapy with $\mathrm{LAM}^{6,8}$. Such patients were included in the IFN-related group (Table 2). Overall, 21 series of antiviral therapy were used during this period (Table 2).

Nine LAM-resistant patients with mutations in the YMDD motif of polymerase gene, six with M204V, two with M204I, and one patient with both, were retreated (Table 3 ). Adefovir ( $10 \mathrm{mg} /$ day) was given to three patients as a second series and one patient as a third series (Table 3). Pegylated interferon (Peg-IFN) was given to five patients, four received Peg-IFN- $\alpha 2 b(1.5 \mu \mathrm{g} / \mathrm{kg}$ of body weight) and one patient received PegIFN- $\alpha 2 \mathrm{a}(180 \mu \mathrm{g})$, all in association with LAM. Finally, tenofovir was given at a dose of $300 \mathrm{mg} /$ day to four unresponsive patients as a rescue drug.

As for the two patients who experienced a relapse after withdrawal of LAM, one (patient 2) presented with a spontaneous absence of serum 


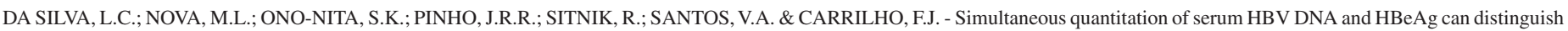
between slow and fast viral responses to antiviral therapy in patients with chronic hepatitis B. Rev. Inst. Med. trop. S. Paulo, 51(5): 261-268, 2009.

Table 2

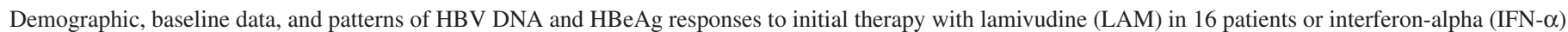
plus LAM in five other patients with chronic hepatitis B $(\mathrm{CH})$ or liver cirrhosis (LC)

\begin{tabular}{|c|c|c|c|c|c|c|c|c|}
\hline $\begin{array}{l}\text { Patient/ } \\
\text { Diagnosis }\end{array}$ & Age/Sex & $\begin{array}{l}\text { HBV DNA } \\
(\log )\end{array}$ & $\begin{array}{c}\text { ALT* } \\
(\mathbf{x U N L})\end{array}$ & $\begin{array}{c}\text { First } \\
\text { therapy }\end{array}$ & $\begin{array}{c}\text { Viral response } \\
\text { (VR) / } \\
\text { (Mutation)** }\end{array}$ & Pattern & $\begin{array}{c}\text { Follow-up } \\
\text { (months) }\end{array}$ & Outcome \\
\hline $1 / \mathrm{CH}$ & $37 / \mathrm{M}$ & 10.48 & 4.5 & LAM & $\mathrm{VR} /(\mathrm{NO})$ & I & 102 & $\begin{array}{l}\text { Seroconversion } \\
\mathrm{HBsAg} / \text { anti-HBs }\end{array}$ \\
\hline $2 / \mathrm{CH}$ & $37 / F$ & 6.48 & 8.8 & LAM & $\mathrm{VR} /(\mathrm{NO})$ & I & 125 & $\begin{array}{l}\text { Relapse } \\
\text { Re-treatment }\end{array}$ \\
\hline $3 / \mathrm{CH}$ & $45 / \mathrm{M}$ & 8.63 & 2.3 & LAM & $\begin{array}{l}\mathrm{VR} /(\mathrm{M} 204 \mathrm{~V}) \\
\quad \text { (late) }\end{array}$ & I & 125 & $\begin{array}{l}\text { Breakthrough (late) } \\
\text { Re-treatment }\end{array}$ \\
\hline 4/LC & $65 / \mathrm{M}$ & 12.48 & 6.9 & LAM & VR / (NO) & I & 109 & $\begin{array}{l}\text { Seroconversion } \\
\text { HBsAg/anti-HBs }\end{array}$ \\
\hline $5 / \mathrm{CH}$ & $48 / \mathrm{M}$ & 8.48 & 1.7 & LAM & BT / (M204V) & II & 109 & $\begin{array}{l}\text { Breakthrough } \\
\text { Re-treatment }\end{array}$ \\
\hline 6/LC & $52 / \mathrm{M}$ & 8.48 & 1.5 & LAM & BT / (M204V/I) & II & 108 & $\begin{array}{l}\text { Breakthrough } \\
\text { Re-treatment }\end{array}$ \\
\hline 7/LC & $42 / \mathrm{M}$ & 10.48 & 3.1 & LAM & $\mathrm{VR} /(\mathrm{NO})$ & IIIA & 90 & $\begin{array}{l}\text { Seroconversion } \\
\mathrm{HBeAg} / \text { anti-HBe }\end{array}$ \\
\hline 8/LC & $59 / \mathrm{M}$ & 7.96 & 8.7 & LAM & $\mathrm{VR} /(\mathrm{NO})$ & IIIA & 48 & $\begin{array}{l}\text { Seroconversion } \\
\mathrm{HBeAg} / \text { anti-HBe }\end{array}$ \\
\hline $9 / \mathrm{CH}$ & $62 / \mathrm{M}$ & 12.48 & 1.7 & LAM & $\mathrm{VR} /(\mathrm{NO})$ & IIIA & 83 & $\begin{array}{l}\text { VR with relapse } \\
\text { Re-treatment }\end{array}$ \\
\hline $10 / \mathrm{CH}$ & $9 / \mathrm{F}$ & 8.48 & 3.3 & LAM & BT / (M204I) & IIIB & 37 & $\begin{array}{l}\text { Breakthrough. } \\
\text { Drop out }\end{array}$ \\
\hline $11 / \mathrm{CH}$ & $34 / \mathrm{M}$ & 5.41 & 2.0 & LAM & BT / (M204I) & IIIB & 95 & $\begin{array}{l}\text { Breakthrough } \\
\text { Re-treatment }\end{array}$ \\
\hline $12 / \mathrm{CH}$ & $11 / \mathrm{M}$ & 10.48 & 0.7 & LAM & NR / (M204I) & NR & 133 & Re-treatment \\
\hline $13 / \mathrm{CH}$ & $30 / \mathrm{M}$ & 8.48 & 2.9 & LAM & NR / (M204V) & NR & 117 & Re-treatment \\
\hline $14 / \mathrm{CH}$ & $43 / \mathrm{M}$ & 10.48 & 1.7 & LAM & NR / (M204V) & NR & 86 & Re-treatment \\
\hline $15 / \mathrm{CH}$ & $44 / \mathrm{M}$ & 10.48 & 1.2 & LAM & NR / (M204V) & NR & 119 & Re-treatment \\
\hline $16 / \mathrm{CH}$ & 49/M & 9.48 & 8.0 & LAM & NR / (M204V) & NR & 103 & $\begin{array}{l}\text { Breakthrough } \\
\text { Re-treatment }\end{array}$ \\
\hline $17 / \mathrm{CH}$ & 29/M & 12.48 & 1.5 & IFN+LAM & $\mathrm{VR} /(\mathrm{NO})$ & I & 85 & $\begin{array}{l}\text { Seroconversion } \\
\mathrm{HBeAg} / \text { anti-HBe }\end{array}$ \\
\hline $18 / \mathrm{CH}$ & $21 / \mathrm{M}$ & 6.48 & 4.2 & IFN+LAM & $\mathrm{VR} /(\mathrm{NO})$ & I & 34 & $\begin{array}{l}\text { Seroconversion } \\
\text { HBeAg/anti-HBe }\end{array}$ \\
\hline $19 / \mathrm{CH}$ & $32 / \mathrm{F}$ & 7.60 & 2.0 & $\underset{* * *}{\mathrm{Peg}+\mathrm{LAM}}$ & $\mathrm{VR} /(\mathrm{NO})$ & IIIA & 72 & $\begin{array}{l}\text { Seroconversion } \\
\mathrm{HBeAg} / \text { anti-HBe }\end{array}$ \\
\hline 20/LC & $11 / \mathrm{F}$ & 6.40 & 0.7 & IFN+LAM & VR / (NO) & IIIA & 62 & $\begin{array}{l}\text { Seroconversion } \\
\mathrm{HBeAg} / \mathrm{anti}-\mathrm{HBe}\end{array}$ \\
\hline $21 / \mathrm{CH}$ & $12 / \mathrm{M}$ & 8.70 & 0.7 & IFN+LAM & $\mathrm{NR} /(\mathrm{NO})$ & NR & 60 & $\begin{array}{l}\text { Under treatment. } \\
\text { Steady drop of } \\
\text { HBV DNA and HB }\end{array}$ \\
\hline
\end{tabular}

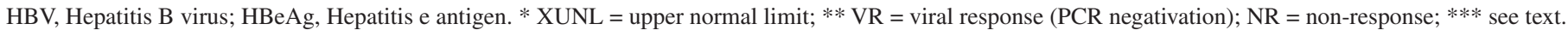

HBeAg but had a persistence of HBV DNA during the non-treatment period and received a second series of LAM with subsequent clearance of the HBV DNA. The other patient (patient 9) was treated with Peg-IFN$\alpha 2 \mathrm{~b}$ plus LAM and presented with an HBsAg/anti-HBs seroconversion. Finally, another patient non-responder to LAM (patient 16) received LAM associated to lobucavir as a rescue drug (withdrawn from the market).
As shown in Table 3, more than two therapeutic series had to be used in three patients (patients 5, 6, and 13). Overall, 15 series of antiviral therapy were used in the retreatment, resulting in a total number of 36 therapeutic series for the two phases. The primary endpoints were an inability to detect HBV DNA and the loss of HBeAg with seroconversion to anti-HBe. 
DA SILVA, L.C.; NOVA, M.L.; ONO-NITA, S.K.; PINHO, J.R.R.; SITNIK, R.; SANTOS, V.A. \& CARRILHO, F.J. - Simultaneous quantitation of serum HBV DNA and HBeAg can distinguish between slow and fast viral responses to antiviral therapy in patients with chronic hepatitis B. Rev. Inst. Med. trop. S. Paulo, 51(5): 261-268, 2009.

Table 3

Patterns of HBV DNA and HBeAg responses in chronic hepatitis B patients previously resistant to lamivudine (LAM)* and submitted to a second or a third anti-viral therapy

\begin{tabular}{|c|c|c|c|c|}
\hline Patient $* *$ & $\begin{array}{l}\text { Type of previous } \\
\text { resistance }\end{array}$ & $\begin{array}{l}\text { Antiviral therapy } \\
\text { (re-treatment) }\end{array}$ & Pattern of response $\mathrm{e}^{* * *}$ & Outcome \\
\hline $2 / \mathrm{CH}$ & Relapse & Lamivudine $* * * *$ & I & $\mathrm{HBeAg} / \mathrm{anti}-\mathrm{HBe}$ seroconversion \\
\hline $3 / \mathrm{CH}$ & M204V & Adefovir & NR & $\begin{array}{l}\text { Late HBVDNA negativation and late } \\
\mathrm{HBe} \mathrm{Ag} / \text { anti-HBe seroconversion }\end{array}$ \\
\hline \multirow[t]{3}{*}{$5 / \mathrm{CH}$} & M204V & PegIFN- $\alpha 2 b+$ Lamivudine & I & Viral response with relapse \\
\hline & & Adefovir & IIIB & HBeAg-non-response \\
\hline & & Tenofovir & IIIA & Profound drop of $\mathrm{HBeAg}$ \\
\hline \multirow[t]{2}{*}{$6 / \mathrm{LC}$} & M204V/M204I & PegIFN- $\alpha 2 b+$ Lamivudine & NR & HBVDNA persistently positive \\
\hline & & Tenofovir & $* * *$ & Clearance of HBVDNA (See table 2) \\
\hline 9/CH & Relapse & PegIFN- $\alpha 2 b+$ Lamivudine & I & HBsAg/anti-HBs seroconversion \\
\hline $11 / \mathrm{CH}$ & M204I & Adefovir & IIIB & Breakthrough \\
\hline $12 / \mathrm{CH}$ & M204I & Tenofovir & IIIA & Under treatment \\
\hline \multirow[t]{2}{*}{$13 / \mathrm{CH}$} & M204V & PegIFN- $\alpha 2 b+$ Lamivudine & I & VR with relapse \\
\hline & & Tenofovir & I & Under treatment \\
\hline $14 / \mathrm{CH}$ & M204V & Adefovir & I & Under treatment \\
\hline $15 / \mathrm{CH}$ & M204V & PegIFN- $\alpha 2 \mathrm{a}+$ Lamivudine & I & $\mathrm{HBe} \mathrm{Ag} / \mathrm{anti}-\mathrm{HBe}$ seroconversion \\
\hline $16 / \mathrm{CH}$ & M204V & Lamivudine+Lobucavir & I & HBsAg/anti-HBs seroconversion \\
\hline
\end{tabular}

HBV, Hepatitis B virus; HBeAg, Hepatitis e antigen. * See Table 1; ** No. according to Table 2; *** NR = non-response; undetectability of HBeAg just before tenofovir; **** See text.

Laboratory methods: Serum samples were available for study at the following time points: initial screening ("baseline"), every three to six months during therapy, and after the completion of therapy. The levels of ALT, HBV DNA, and HBeAg were available at each time point. The serum ALT levels were tested using commercially available assays (Abbott Laboratories). Results are expressed as values times the upper normal limit (x UNL). The semi-quantitation of serum HBeAg was performed prospectively and simultaneously with the determination of serum HBV DNA. Because no commercial assay was available for measuring the $\mathrm{HBeAg}$ concentration, a micro-particle enzyme immunoassay (MEIA, AxSYM HBe 2.0, Abbott Laboratories, Abbott Park, IL) was used ${ }^{13}$. The assay is based on two different monoclonal antibodies, and its reference preparation for quantitation of $\mathrm{HBeAg}$ makes use of purified recombinant $\mathrm{HBeAg}$ as a control. Results are expressed as an index (sample to cutoff $=\mathrm{S} / \mathrm{CO}$ ) luminescent values ratio $^{27}$.

In 17 patients, the quantitation of HBV DNA was performed by inhouse PCR based on Kaneko's method ${ }^{17,18}$ and as previously described ${ }^{6,8}$. The sensitivity of the method was reported to be $3 \times 10^{2}$ copies $/ \mathrm{mL}$, and its dynamic range went up to $3 \times 10^{12}$ copies $/ \mathrm{mL}$. Quantitative results were estimated based on end-point dilutions. In the last four patients (patients 18 to 21), the serum HBV DNA was determined by the Cobas Amplicor HBV Monitor Test (Roche Diagnostics, Branchburg, NJ) with a linear range from $4 \times 10^{2}$ (lower limit of detection) to $4 \times 10^{7}$ copies $/ \mathrm{mL}^{27}$. We have recorded the HBV-DNA levels in copies/mL instead of IU/mL as recently reported ${ }^{19}$.
A virologic response was defined as a decrease in serum HBV DNA to undetectable levels by PCR and a loss of $\mathrm{HBeAg}^{25}$. Patients who showed neither of these serological features were considered to be non-responders, and those who presented with only one type of response (HBV DNA or HBeAg) were classified according to the patterns as described below. A sustained response was defined as the persistence of a virologic response for six months after the discontinuation of therapy ${ }^{25}$. The clearance of $\mathrm{HBeAg}$ and HBsAg was defined as the absence of the particular antigen in two consecutive samples at least one month apart. Viral polymerase, precore/core, and surface genes were sequenced to determine mutations in the YMDD domain as previously described ${ }^{8,32}$.

Liver biopsies: Liver biopsy was performed with a Tru-cut (Baxter Health Care, Deerfield, IL, USA) needle in 20 out of 21 patients. The exception was a cirrhotic patient with ascitis and very low platelet counts.

\section{RESULTS}

Demographic and baseline characteristics of patients: The demographics, baseline data, and patterns of initial therapeutic response for the patients studied are shown in Tables 1,2, and 3. Changes in the $\mathrm{HBeAg} /$ anti-HBe system were observed in $15 / 21$ patients, and the behavior of serum HBeAg expression during a long-term follow-up will be further detailed.

As shown in Table 2, a relapse after withdrawal, viral breakthrough, 
DA SILVA, L.C.; NOVA, M.L.; ONO-NITA, S.K.; PINHO, J.R.R.; SITNIK, R.; SANTOS, V.A. \& CARRILHO, F.J. - Simultaneous quantitation of serum HBV DNA and HBeAg can distinguish between slow and fast viral responses to antiviral therapy in patients with chronic hepatitis B. Rev. Inst. Med. trop. S. Paulo, 51(5): 261-268, 2009.

or non-response was detected in 13/21 (61.9\%) patients and in 12/16 $(75.0 \%)$ patients receiving monotherapy with LAM. Sequencing the YMDD motif in non-responders receiving LAM revealed the M204V mutation in six patients, the M204I mutation in three, and a mixed M204V/I mutation in one patient (Table 2). All but one patient (patient 10) were submitted to re-treatment as stated in Methods (Table 3).

Simultaneous analysis of HBV DNA and HBeAg and characterization of decay patterns: The main goal of our study was to describe the response of HBV to treatment by comparing the patterns of HBV DNA and HBeAg decreases. The results from treated and retreated patients were analyzed together. Overall, 36 series of therapy were obtained.

Three different response patterns could be characterized in our patients: Pattern I was characterized by a simultaneous decrease in serum HBV DNA and HBeAg levels until they were absent within a period of six months (Fig. 1A). If the absence of HBV DNA was followed by the loss of $\mathrm{HBeAg}$ in a maximum period of six months, the pattern was still considered as Pattern I.

A concomitant decrease in HBV DNA and HBeAg was observed in 13/36 (36.1\%) series as shown in Tables 2 and 3. An example of this pattern is shown in Fig. 1A for patient 15, who had previous resistance to LAM due to the M204V mutation and an excellent response to a combined therapy with Peg-IFN- $\alpha 2 \mathrm{a}$ (180 $\mu \mathrm{g}$ per week) and LAM. Pattern I during LAM or interferon plus LAM was detected in 4/16 patients $(15 \%)$ and $6 / 10$ patients $(60 \%)$, respectively $(p=0.10$, twotailed Fisher exact test).

Pattern II was characterized by the persistence of viremia (HBV DNA levels above 1,000 copies/mL) simultaneous with undetectable $\mathrm{HBeAg}$ (Fig. 1B) for a period greater than six months.

This pattern was observed in 2/36 (5.6\%) series. In one patient (patient 5), this pattern was detected during 10 months of therapy with
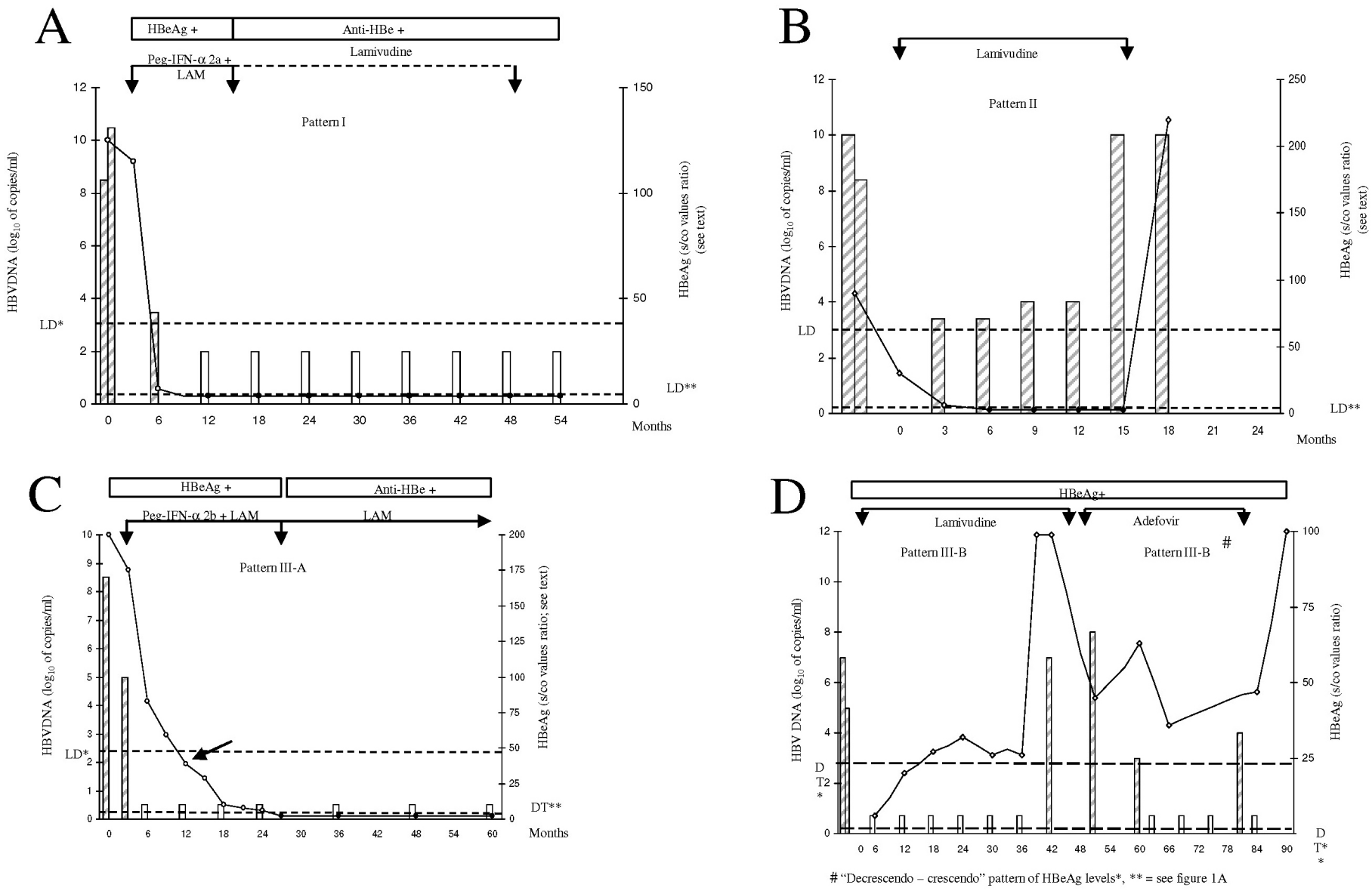

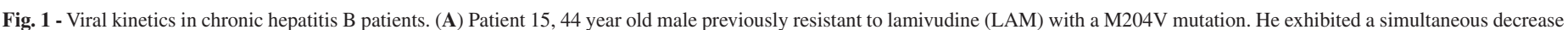

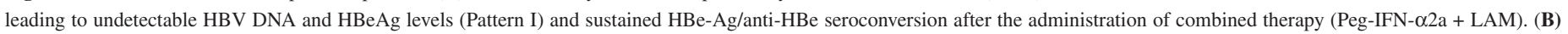

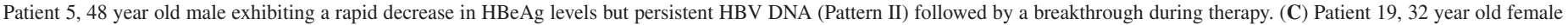

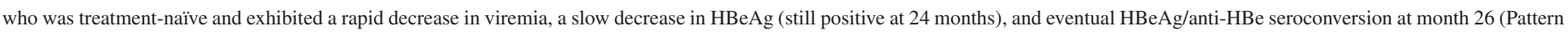

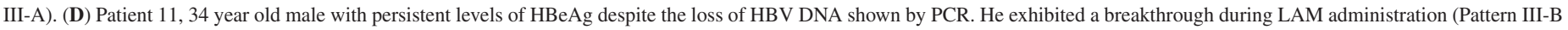

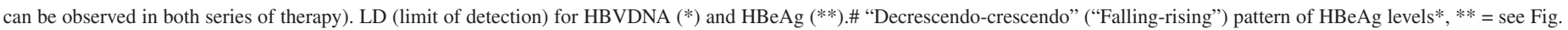

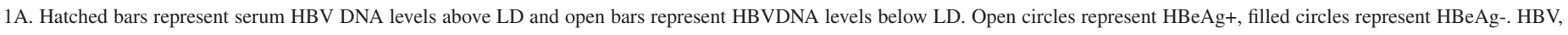
Hepatitis B virus; HBeAg, Hepatitis e antigen. 
DA SILVA, L.C.; NOVA, M.L.; ONO-NITA, S.K.; PINHO, J.R.R.; SITNIK, R.; SANTOS, V.A. \& CARRILHO, F.J. - Simultaneous quantitation of serum HBV DNA and HBeAg can distinguish between slow and fast viral responses to antiviral therapy in patients with chronic hepatitis B. Rev. Inst. Med. trop. S. Paulo, 51(5): 261-268, 2009.

LAM, but $\mathrm{HBeAg}$ became positive thereafter (Fig. 1B). In another patient (patient 6), a loss of HBeAg was observed during therapy with LAM and persisted to be negative throughout despite the high levels of HBV DNA over three years. However, a clearance of serum HBV DNA was detected three months after the administration of tenofovir.

Pattern III was characterized by the persistence of detectable HBeAg despite the absence of HBV DNA for a period greater than six months. In some of these patients, a slow but steady decline of $\mathrm{HBeAg}$ was observed and was referred to as Pattern III-A (Fig. 1C).

In other patients, $\mathrm{HBeAg}$ decreased followed by an increase in serum levels, or it did not change at all, despite the absence of HBV DNA and was referred to as Pattern III-B (Fig. 1D).

The absence of HBV DNA preceding the loss of HBeAg for more than six months was observed in 11/36 therapeutic series (30.6\%).

Pattern III-A was observed in seven patients. Prolonged periods of $\mathrm{HBeAg}$ positivity with continuously decreasing levels indicate a good, but slow, viral response (Fig. 1C). One patient (No. 19) with chronic hepatitis B, very high viremia (above $4 \times 10^{7}$ copies $/ \mathrm{mL}$ by the Amplicor Monitor technique), and a high level of HBeAg was submitted to a combined therapy with Peg-IFN- $\alpha 2 b$ and LAM. As seen in Fig. $1 \mathbf{C}$, HBV DNA became undetectable at the third month. A slow but steady decrease of $\mathrm{HBeAg}$ was observed.

Pattern III-B was observed in the other four patients, all of them presenting a viral relapse (Fig. 1D). As seen in Tables 2 and 3, $\mathrm{HBeAg} /$ anti-HBe seroconversion was detected in $5 / 6$ patients who exhibited Pattern III-A, whereas no viral response was seen in the four patients exhibiting Pattern III-B.

In non-responder patients with persistent serum HBV DNA and $\mathrm{HBeAg}$, and in patients presenting with Pattern III-B, the levels of $\mathrm{HBeAg}$ varied widely either in a "falling-rising" ("decrescendo-crescendo") pattern or with fluctuating values ${ }^{27,31}$.

The small number of patients in each group did not allow a statistical comparison among the different patterns.

In one patient, all three patterns of viral response were observed, as seen in Fig. 2.

The ALT levels varied widely independently of the described patterns and were not included in this analysis.

\section{DISCUSSION}

Based on the simultaneous quantitative determinations of serum HBV DNA and HBeAg, our results suggest that the HBV kinetics can vary widely, depending on the antiviral drugs used for the treatment of HBeAg-positive patients with chronic hepatitis B. The kinetics of HBV have been investigated, but some problems still need clarification ${ }^{22,26}$.

Our results suggest that patients with positive HBeAg levels are less responsive to LAM or adefovir than combined therapy with interferon and LAM or tenofovir. Thus, Pattern I, which is characterized by the simultaneous decrease of HBV DNA and of $\mathrm{HBeAg}$ in a maximum

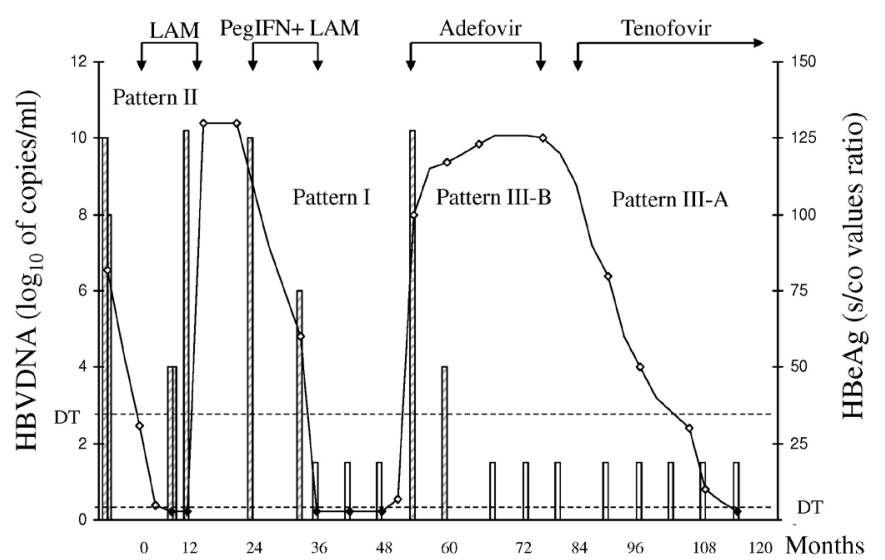

Fig. 2 - The appearance of four different patterns in the same patient during different series of therapy. Patient 5, 48 year old male presented initially with persistence of HBV DNA under lamivudine (LAM) treatment despite the temporary clearance of HBeAg (Pattern II). Patterns II, I, III-B, and III-A emerged during LAM,Peg-IFN- $\alpha-2 b+L A M$, adefovir, and tenofovir treatment (arrows), respectively. HBV, Hepatitis B virus; HBeAg, Hepatitis e antigen.

period of six months, is more frequently found during treatment with interferon plus LAM or during tenofovir treatment. This pattern presents a favorable evolution in most cases, though a relapse or breakthrough is occasionally found. Pattern II was detected in very few cases and must be investigated with a larger number of patients. In our patients a breakthrough was found.

Our patients were followed for periods of time varying from 34 months to 133 months. Such long periods allowed us to observe that different patterns of serum $\mathrm{HBeAg}$ changes can be present in the same patient, and it allowed us to note how unpredictable the outcomes of patients on and off antiviral therapy are ${ }^{7}$. Despite the role of HBV DNA quantitation, the rapid and dramatic decrease in viremia after the introduction of nucleoside analogues reinforces the necessity to quantify $\mathrm{HBeAg}$ levels during the period of $\mathrm{HBeAg}$ positivity as an additional marker for monitoring responses. In some patients, a progressive drop in HBeAg levels may be paralleled with an HBV DNA decrease (Pattern I), but in other patients, the decrease of $\mathrm{HBeAg}$ is steady and slow, pointing to a late response (Pattern III-A)

A progressive decrease in serum $\mathrm{HBeAg}$ has been referred as a "decrescendo" ("falling") pattern and a decrease in HBeAg followed by a return to high levels as a "decrescendo-crescendo" ("falling-rising") pattern $^{27,31}$. The first pattern is predictive of a viral response, whereas most of the patients who fail to show a continuous decrease in $\mathrm{HBeAg}$ levels present with a viral breakthrough or non-response. The characteristics of our study do not allow for a close comparison with the above-mentioned patterns.

Possibly an immune-modulating protein, $\mathrm{HBeAg}$ is a nonstructural secreted protein translated from HBV e (precore and core) mRNA. On the other hand, $\mathrm{HBcAg}$, the major protein of the HBV capsid, is translated from HBV pregenomic mRNA ${ }^{21}$. Since $\mathrm{HBeAg}$ and $\mathrm{HBcAg}$ share a sequence consisting of 149 amino acids, they are collectively called Hepatitis B core-related antigens. The measurement of these antigens would be particularly useful for monitoring the decline of viral 


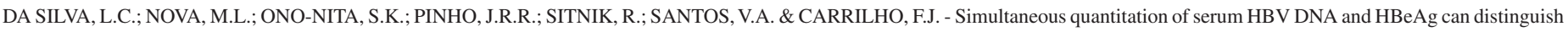
between slow and fast viral responses to antiviral therapy in patients with chronic hepatitis B. Rev. Inst. Med. trop. S. Paulo, 51(5): 261-268, 2009.

translation activity. It would also allow for a comparison of the efficacies of potent antiviral drugs when a large proportion of patients have HBV DNA below the detection threshold ${ }^{21}$. ROKUHARA et al..$^{29}$ reported that five out of six patients treated with LAM for six to eight months still had detectable levels of core-related antigen. A similar result was also seen in another study ${ }^{34}$ after 48 weeks of nucleoside analogue therapy; $65 \%$ of the patients who had undetectable serum HBV DNA $(<300$ copies/ $\mathrm{mL})$ still had detectable core-related antigen.

Persistent and steady levels of $\mathrm{HBeAg}$ for a prolonged period of time, despite the absence of HBV DNA (Pattern III-B) may indicate some degree of resistance and herald a breakthrough, as was observed in some of our patients. This observation led us to switch adefovir for tenofovir in one patient, and a sharp decrease of HBeAg was observed (Fig. 2). On the other hand, a progressive decrease in HBeAg points to a favorable response, even when the persistence of $\mathrm{HBeAg}$ is as long as 26 months of therapy. As seen in Fig. 1C, such a long-term persistence might lead to a withdrawal of the combined therapy of Peg-IFN and LAM. As could be predicted by the trend of Pattern III-A in these patients, the loss of $\mathrm{HBeAg}$ and seroconversion to anti-HBe was a late event during this therapy.

Previous results ${ }^{6}$ had also showed that a non-response to LAM is mainly observed in patients with high viremia, and most of them were positive for $\mathrm{HBeAg}$. This correlation was so significant that a proportion between the probability of non-response and an increase in the logarithm of genome copies per $\mathrm{mL}$ could be established. The above-mentioned differences in viral dynamics are not surprising as nucleotide analogues produce a decrease in viral load mainly through a block of viral replication, whereas interferon acts directly through some intracellular antiviral pathways and indirectly through a modulation of the immune system.

Daily LAM doses of $300 \mathrm{mg}$ may lead to an earlier ${ }^{9,15}$ and more profound suppression of HBV DNA ${ }^{15}$. In a previous paper, we showed a rapid decrease in serum HBV DNA in 27 out of 29 patients (93\%) whose quantitation was performed after 12 weeks of LAM treatment ${ }^{6}$. This response was demonstrated by three different quantitative methods: endpoint dilution, Amplicor-Monitor (Roche), and branched DNA. The endpoint dilution method using 10-fold serial dilutions was also used by YOTSUYANAGI et al. ${ }^{35}$ Our data suggests that combination therapy with PEG-IFN and LAM usually produces a concomitant decrease of $\mathrm{HBe} \mathrm{Ag}$ and HBV DNA, whereas monotherapy with LAM or adefovir may produce a rapid decrease in HBV DNA, but result in a slow, or lack of, decrease of $\mathrm{HBeAg}$ in some patients.

Studies in patients with chronic hepatitis B have reported conflicting results regarding the benefits of combining IFN- $\alpha$ or PEG-IFN and LAM, and the role of such combinations in chronic hepatitis $\mathrm{B}$ treatment requires further clarification. According to TER BORG et al. ${ }^{33}$, the HBV DNA decline after 52 weeks of therapy was significantly higher in patients undergoing combined therapy (PEG-IFN plus LAM) compared to those undergoing monotherapy with PEG-IFN.

The most important limitation of this study relates to the small number of patients and therapeutic series. Despite these limitations, our study provides some evidence that the decrease in serum HBV DNA accompanied by a steady decrease in HBeAg (Pattern I), even when it is slow (Pattern III-A), points to a favorable outcome. As was also recently proposed for hepatitis $\mathrm{C}$ patients ${ }^{2}$, the use of customized treatment for each patient may increase the likelihood of a response, and following up on HBV DNA and HBeAg levels helps in choosing the best treatment for each patient as well in predicting treatment response. It must be emphasized that stopping rules based on HBV DNA determination for PEG-IFN treatment could not be established ${ }^{10}$. Furthermore, our data suggests that the period of 48 weeks for the discontinuation of PEG-IFN may be too short in some patients.

In conclusion, three different patterns can be observed for HBV DNA and $\mathrm{HBeAg}$ levels over time when quantitative PCR and HBeAg (MEIA AxSYM) techniques are used simultaneously. A more detailed study with different therapy schedules and using both methods in a large number of patients with chronic hepatitis B is urgently needed.

\section{RESUMO}

A quantificação simultânea do DNA VHB e do AgHBe séricos podem distinguir entre resposta viral lenta e rápida à terapêutica anti-viral em pacientes com hepatite crônica $B$

Introdução: A quantificação do AgHBe sérico não é habitualmente utilizada para monitorizar a resposta viral ao tratamento da hepatite crônica B. Métodos: Neste estudo, 21 pacientes sob tratamento com diferentes terapias foram acompanhados e a resposta viral monitorizada pela quantificação concomitante da carga viral e do AgHBe a fim de investigar o significado e a cinética de ambos os parâmetros. Resultados: Distinguiram-se três diferentes padrões de resposta viral. O primeiro caracterizou-se pela redução simultânea do HBV DNA e AgHBe séricos. $\mathrm{O}$ segundo padrão caracterizou-se por uma redução do AgHBe porém com detecção persistente do HBV DNA. O terceiro padrão caracterizouse por HBV DNA indetectável com positividade persistente do AgHBe, sugerindo ausência de resposta (Padrão III-B), exceto quando os níveis de $\mathrm{AgHBe}$ mostraram uma queda lenta porém persistente, caracterizando um "respondedor lento" (Padrão III-A). Conclusões: O primeiro padrão é compatível com resposta viral. Uma seropositividade prolongada do AgHBe porém com uma redução lenta e persistente (Padrão III-A) é também compatível com resposta viral, sugerindo o prolongamento do tratamento anti-viral.

\section{COMPETING INTERESTS}

The authors declare that they have no competing interests.

LCDS conceived of the study, participated in its design and coordination, and drafted the manuscript. MLDN participated in its design and drafted the manuscript, SKON participated in its design and drafted the manuscript, JRRP participated in its design and drafted the manuscript, RS participated in drafting the manuscript, VADS carried out the immunoassays, and FJC participated in its design and drafted manuscript. All authors read and approved the final manuscript.

\section{ACKNOWLEDGMENTS}

This study was supported in part by research grants from the Alves de Queirós Family Fund for Research and CNPq. 
DA SILVA, L.C.; NOVA, M.L.; ONO-NITA, S.K.; PINHO, J.R.R.; SITNIK, R.; SANTOS, V.A. \& CARRILHO, F.J. - Simultaneous quantitation of serum HBV DNA and HBeAg can distinguish between slow and fast viral responses to antiviral therapy in patients with chronic hepatitis B. Rev. Inst. Med. trop. S. Paulo, 51(5): 261-268, 2009.

\section{REFERENCES}

1. ALBERTI, A. - Can serum HBV-DNA be used as a primary end point to assess efficacy of new treatments for chronic hepatitis B? Hepatology, 38: 18-20, 2003.

2. BUTI, M.; CASADO, M.A. \& ESTEBAN, R. - Evaluating the cost of sustained virologic response in naive chronic hepatitis $\mathrm{C}$ patients treated a la carte. Aliment. Pharmacol. Ther., 26: 705-716, 2007.

3. CHANG, T.T.; GISH, R.G.; DE MAN, R. et al. - A comparison of entecavir and lamivudine for HBeAg-positive chronic hepatitis B. New Engl. J. Med., 354: 1001-1010, 2006.

4. CONJEEVARAM, H.S. \& LOK, A.S. - Management of chronic hepatitis B. J. Hepat., 38 (suppl. 1): S90-S103, 2003.

5. CORDEN, S.; BALLARD, A.L.; IJAZ, S. et al. - HBV DNA levels and transmission of hepatitis B by health care workers. J. clin. Virol., 27: 52-58, 2003.

6. DA SILVA, L.C.; DA FONSECA, L.E.; CARRILHO, F.J. et al. - Predictive factors for response to lamivudine in chronic hepatitis B. Rev. Inst. Med. trop. S. Paulo, 42: 189-196, 2000.

7. DA SILVA, L.C.; ONO-NITA, S.K.; PINHO, J.R. \& CARRILHO, F.J. - Variable and unpredictable outcome in chronic hepatitis $\mathrm{B}(\mathrm{CHB})$ patients during and after therapy with high daily doses of lamivudine (LAM). Hepatology, 36: 638A, 2002.

8. DA SILVA, L.C.; PINHO, J.R.; SITNIK, R.; DA FONSECA, L.E. \& CARRILHO, F.J. - Efficacy and tolerability of long-term therapy using high lamivudine doses for the treatment of chronic hepatitis B. J. Gastroent., 36: 476-485, 2001.

9. DIENSTAG, J.L.; PERRILLO, R.P.; SCHIFF, E.R. et al. - A preliminary trial of lamivudine for chronic hepatitis B infection. New Engl. J. Med., 333: 1657-1661, 1995.

10. FRIED, M.W.; PIRATVISUTH, T.; LAU, G.K. et al. - HBeAg and hepatitis B virus DNA as outcome predictors during therapy with peginterferon alfa-2a for $\mathrm{HBeAg}$-positive chronic hepatitis B. Hepatology, 47: 428-434, 2008.

11. FUNG, S.K. \& LOK, A.S. - Treatment of chronic hepatitis B: who to treat, what to use, and for how long? Clin. Gastroent. Hepat., 2: 839-848, 2004.

12. HEIJTINK, R.A.; JANSSEN, H.L.; HOP, W.C.; OSTERHAUS, A.D. \& SCHALM, S.W. - Interferon-alpha therapy in chronic hepatitis B: early monitoring of hepatitis B e antigen may help to decide whether to stop or to prolong therapy. J. viral Hepat., 7: 382-386, 2000

13. HEIJTINK, R.A.; KRUINING, J.; HONKOOP, P. et al. - Serum HBeAg quantitation during antiviral therapy for chronic hepatitis B. J. med. Virol., 53: 282-287, 1997.

14. HO, S.K.; YAM, W.C.; LEUNG, E.T. et al. - Rapid quantification of hepatitis B virus DNA by real-time PCR using fluorescent hybridization probes. J. med. Microbiol., 52: 397-402, 2003.

15. HONKOOP, P.; DE MAN, R.A.; NIESTERS, H.G. et al. - Quantitative hepatitis B virus DNA assessment by the limiting-dilution polymerase chain reaction in chronic hepatitis B patients: evidence of continuing viral suppression with longer duration and higher dose of lamivudine therapy. J. viral. Hepat., 5: 307-312, 1998.

16. JARDI, R.; RODRIGUEZ, F.; BUTI, M. et al. - Quantitative detection of hepatitis B virus DNA in serum by a new rapid real-time fluorescence PCR assay. J. viral Hepat., 8: 465-471, 2001.

17. KANEKO, S.; FEINSTONE, S.M. \& MILLER, R.H. - Rapid and sensitive method for the detection of serum hepatitis B virus DNA using the polymerase chain reaction technique. J. clin. Microbiol., 27: 1930-1933, 1989.

18. KANEKO, S, MILLER, R.H.; DI BISCEGLIE, A.M. et al. - Detection of hepatitis B virus DNA in serum by polymerase chain reaction. Application for clinical diagnosis. Gastroenterology, 99: 799-804, 1990.
19. KEEFFE, E.B.; DIETERICH, D.T. HAN, S.H. et al. - A treatment algorithm for the management of chronic hepatitis B virus infection in the United States. Clin. Gastroent. Hepat., 2: 87-106, 2004

20. KEEFFE, E.B.; ZEUZEM, S.; KOFF, R.S. et al. - Report of an international workshop: roadmap for management of patients receiving oral therapy for chronic hepatitis B. Clin. Gastroent. Hepat., 5: 890-897, 2007.

21. KIMURA, T.; OHNO, N.; TERADA, N. et al. - Hepatitis B virus DNA-negative Dane particles lack core protein but contain a $22-\mathrm{kDa}$ precore protein without $\mathrm{C}$-terminal arginine-rich domain. J. biol. Chem., 280: 21713-21719, 2005.

22. LEWIN, S.R.; RIBEIRO, R.M.; WALTERS, T. et al. - Analysis of hepatitis B viral load decline under potent therapy: complex decay profiles observed. Hepatology, 34: 1012-1020, 2001.

23. LOK, A.S.; HEATHCOTE, E.J. \& HOOFNAGLE, J.H. - Management of hepatitis B 2000--summary of a workshop. Gastroenterology, 120: 1828-1853, 2001.

24. LOK, A.S. \& McMAHON, B.J. - Chronic hepatitis B: update of recommendations Hepatology, 39: 857-861, 2004.

25. LOK, A.S. \& McMAHON, B.J. - Chronic hepatitis B. Hepatology, 45: 507-539, 2007.

26. NEUMANN, A.U. - Hepatitis B viral kinetics: a dynamic puzzle still to be resolved. Hepatology, 42: 249-254, 2005.

27. PARK, N.H.; SHIN, J.W.; PARK, J.H. et al. - Monitoring of HBeAg levels may help to predict the outcomes of lamivudine therapy for $\mathrm{HBeAg}$ positive chronic hepatitis B. J. viral Hepat., 12: 216-221, 2005.

28. PERRILLO, R.; MIMMS, L.; SCHECHTMAN, K.; ROBBINS, D. \& CAMPBELL, C. Monitoring of antiviral therapy with quantitative evaluation of $\mathrm{HBeAg}$ : a comparison with HBV DNA testing. Hepatology, 18: 1306-1312, 1993.

29. ROKUHARA, A.; TANAKA, E.; MATSUMOTO, A. et al. - Clinical evaluation of a new enzyme immunoassay for hepatitis B virus core-related antigen; a marker distinct from viral DNA for monitoring lamivudine treatment. J. viral Hepat., 10: 324-330, 2003.

30. SHAW, T.; BOWDEN, S. \& LOCARNINI, S. - Chemotherapy for hepatitis B: new treatment options necessitate reappraisal of traditional endpoints. Gastroenterology, 123: 2135-2140, 2002.

31. SHIN, J.W.; PARK N.H.; JUNG, S.W. et al. - Clinical significance of hepatitis B e antigen level measurement during long-term lamivudine therapy in chronic hepatitis B patients with e antigen positive. Wld J. Gastroent., 12: 6693-6698, 2006.

32. SITNIK, R.; PINHO, J.R.; BERTOLINI, D.A. et al. - Hepatitis B virus genotypes and precore and core mutants in Brazilian patients. J. clin. Microbiol., 42: 2455-2460, 2004 .

33. TER BORG, M.J.; VAN ZONNEVELD, M.; ZEUZEM, S. et al. - Patterns of viral decline during PEG-interferon alpha-2b therapy in $\mathrm{HBeAg}$-positive chronic hepatitis B: relation to treatment response. Hepatology, 44: 721-727, 2006.

34. WONG, D.K.; TANAKA, Y.; LAI, C.L. et al. - Hepatitis B virus core-related antigens as markers for monitoring chronic hepatitis B infection. J. clin. Microbiol., 45: 3942-3947, 2007.

35. YOTSUYANAGI, H.; YASUDA, K.; IINO, S. et al. - Persistent viremia after recovery from self-limited acute hepatitis B. Hepatology, 27: 1377-1382, 1998.

Received: 23 March 2009

Accepted: 28 September 2009 